\title{
High-grade mucoepidermoid carcinoma in thyroglossal cyst: Post-surgical histological surprise and dilemmas
}

\author{
Ravindran Chirukandath ${ }^{1}$, Nimisha $\mathrm{CR}^{2}$, Babu $\mathrm{PJ}^{3}$, Arya Puthukatt Muraleedharan ${ }^{4}$, \\ Lekshmi RS ${ }^{5}$, Santhosh TV ${ }^{6}$ \\ ${ }^{1}$ Additional Professor, ${ }^{2}$ Assistant Professor, ${ }^{3}$ Professor and Head, ${ }^{5}$ Junior Resident, ${ }^{6}$ Associate Professor, Department \\ of General Surgery, Government Medical College, Thrissur, Kerala, India, ${ }^{4}$ Senior Resident, Department of Pathology, \\ Government Medical College, Thrissur, Kerala, India
}

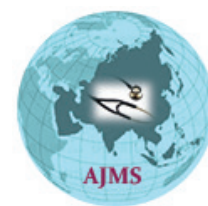

\section{A B S T R A C T}

Occurrence of malignancy in the TG cyst has been rarely reported, though rare, and papillary carcinoma predominates the common type but squamous cell carcinomas, anaplastic carcinoma, and medullary have been reported rarely. Mucoepidermoid carcinomas are most commonly seen in salivary glands, and as per the available literature, there was only two cases reported in thyroglossal cyst. We are presenting a 67-year-old lady presented with a $6 \times 8 \mathrm{~cm}$ hard swelling below symphysis menti with no thyromegaly and moving on protrusion of tongue, and on MRI, it was found to be thyroglossal cyst with infiltration of strap muscles. Cytological investigation revealed it to be a TG cyst malignancy. The patient underwent total thyroidectomy and radical Sistrunk's operation. Histopathological and immunohistochemistry revealed it to be a histological examination revealed a low-grade mucoepidermoid carcinoma consistent with origin in a thyroglossal duct remnant it invaded the hyoid bone and adjacent strap muscles. Various diagnostic and treatment dilemmas in the treatment of TG cyst malignancy are discussed with reference to mucoepidermoid carcinoma. We are reporting an usual histological surprise in a thyroglossal cyst malignancy being the only second reported case of TG cyst mucoepidermoid carcinoma this case highlights the importance of removal of thyroglossal duct cysts at an early stage and aggressive surgical approach in high-grade tumors.

Key words: TG cyst; Mucoepidermoid carcinoma; Sistrunk's operation; High grade

\section{Access this article online}

Website:

http://nepjol.info/index.php/AJMS DOI: 10.3126/ajms.v12i12.39652

E-ISSN: 2091-0576

P-ISSN: 2467-9100

Copyright (c) 2021 Asian Journal of Medical Sciences

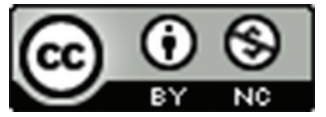

This work is licensed under a Creative Commons Attribution-NonCommercial 4.0 International License.

\section{INTRODUCTION}

Thyroglossal cyst is the most common congenital abnormality of thyroid gland development affecting pediatric age group but also in older age group. ${ }^{1}$ Thyroglossal cyst can have ectopic thyroid tissue varied from $1.5 \%$ to $45 \%$ of cases. $^{2}$

Occurrence of malignancy in the cyst has been rarely reported, though rare and till date, 278 cases are reported in the literature $e^{3}$ and papillary carcinoma predominates the common type but squamous cell carcinomas, anaplastic carcinoma, and medullary have been reported rarely.
Mucoepidermoid carcinomas are most commonly seen in salivary glands, however, it is also reported from glandular tissue of lung, lacrimal glands, and thyroid. There are around 42 cases of mucoepidermoid carcinomas from world literature and mostly they are low grade. We are reporting the second reported case of mucoepidermoid carcinoma in thyroglossal cyst with local infiltration. There are diagnostic and management dilemmas in this condition and consensus is yet to be reached.

We are presenting a 67-year-old lady presented with a $6 \times 8 \mathrm{~cm}$ hard swelling below symphysis menti with no thyromegaly and moving on protrusion of tongue, and on MRI, it was found to be thyroglossal cyst with infiltration 
of strap muscles. Cytological investigation revealed it to be a TG cyst malignancy. The treatment plan and histopathological surprise that followed is discussed in detail.

\section{PRESENTATION OF THE CASE}

A 67-year-old lady presented to general surgery OPD, with complaints of a swelling below chin in the upper neck which she noticed 5 months back. Swelling was painless, moving with deglutition and rapidly progressed in size. There was associated discomfort while swallowing. She was known hypertensive on antihypertensives. Clinical examination revealed that there was a $6 \times 8 \mathrm{~cm}$ sized oval hard non-tender swelling in submental region in midline extending from $2 \mathrm{~cm}$ below symphysis menti to just above the level of hyoid bone, and $3 \mathrm{~cm}$ to the midline on either side. It was moving with deglutition and with the protrusion of tongue. Thyroid gland was not enlarged. NO palpable cervical lymphnodes. Oral cavity examination was normal.

Ultrasound neck reported as heterogeneous lesion with necrotic collection in submental region in midline measuring $2.5 \times 2 \times 2 \mathrm{~cm}$ with bilateral sub-centimetric level 3 and 4 lymph nodes.

MRI scan was taken which showed an ill-defined heterogeneously enhancing soft-tissue lesion $39 \times 37 \times$ $24 \mathrm{~mm}$ in midline in submental pre-hyoid region extending to anterior surface of thyroid cartilage (Figure 1) which appears to be embedded in the left strap muscles. Few intralesional cystic areas noted. Lesion was found to be extending posteriorly in pre epiglottic region. Mild bone marrow edema of hyoid bone and thyroid cartilage noted, findings were suggestive of thyroglossal duct cyst lesion with possible malignant infiltration. Thyroid gland visualized normally with no focal lesions.

Fine-needle cytology showed cells suggestive of papillary carcinoma. The patient was prepared was operated. On exploration there a $4 \times 5 \mathrm{~cm}$ hard lesion above the Hyoid This lesion was found to be infiltrating right strap muscles and body of hyoid. Thyroid appeared to be normal morphology. We proceeded with Sistrunk operation along with total thyroidectomy and Level VI central nodal dissection [Figure 2].

Histological examination revealed a low-grade mucoepidermoid carcinoma consistent with origin in a thyroglossal duct remnant. It invaded the hyoid bone and adjacent strap muscles [Figure 3].

\section{DISCUSSION}

Carcinoma arising in a TGDC is a very rare and accounts for less than 1\%. ${ }^{4}$ Approximately 280 cases of malignant tumors in thyroglossal cyst are reported up to 2020 and rarely thereafter. Most common histological type is papillary carcinoma (80-95\%) followed by mixed papillary-follicular carcinoma $(8 \%)$ and squamous cell carcinoma $(6 \%) .^{5}$ It also has to be noted that other cancers such as follicular, squamous cell carcinoma, and Hurtle cell carcinoma are described rarely in the literature. ${ }^{6}$ Very rarely there are

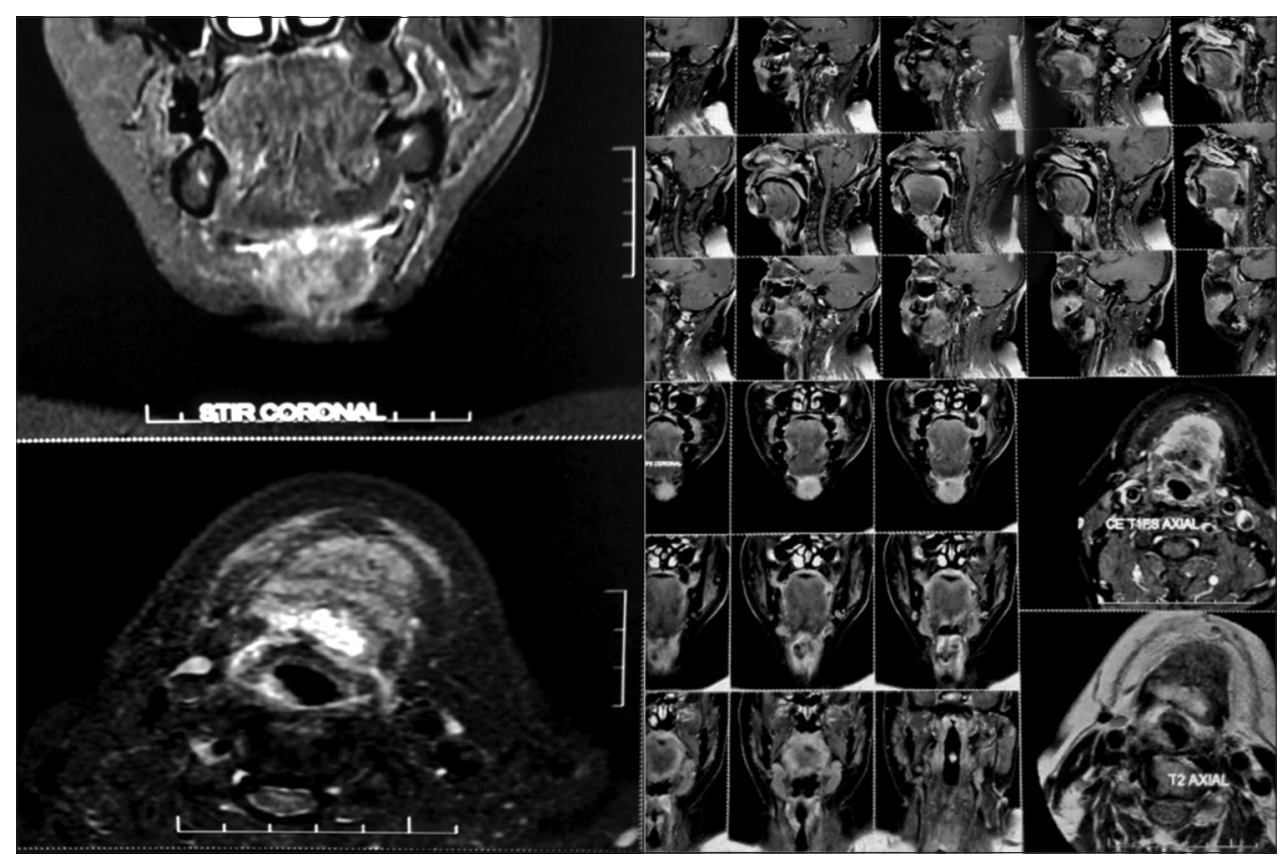

Figure 1: MRI shows an ill-defined heterogeneously enhancing soft-tissue lesion $39 \times 37 \times 24 \mathrm{~mm}$ in midline in submental pre-hyoid region extending to anterior surface of thyroid cartilage which appears to be embedded in the left strap muscles. 
reported cases of anaplastic carcinoma and one reported case of mucoepidermoid carcinoma. It is very important to emphasize that genetic positivity of TITF1, TITF2, and PAX8 and the gene for the thyroid-stimulating hormone receptor.

The knowledge about the thyroid mucoepidermoid carcinoma is still evolving and it is shown that these low-grade tumors are shown to be positive for the $\mathrm{t}(11 ; 19)$ (q21;p13) translocation ${ }^{7-10}$ but the lack of this translocation in high-grade tumors points to the fact that these tumors are biologically and molecularly different entity. The histogenesis of thyroid or thyroglossal cyst $\mathrm{MEC}$ is explained by two theories that it develops from solid cell nests (SCNs) or thyroid follicular epithelial cells. ${ }^{11}$

These SCNs are multipotent cells which have been linked to several thyroid cancers, including papillary and MEC. Alternatively, it is thought that papillary carcinoma (the most common malignancy found in thyroglossal duct remnants) may undergo squamous and mucinous metaplasia resulting in MEC. ${ }^{12,13}$ However, it is still unclear that MEC in a thyroglossal duct remnant has arisen through the same means as a thyroid MEC or through another as yet unspecified mechanism.

Even though the treatment of thyroglossal duct carcinoma is still evolving, consensus have been attained in most areas. Conservative management with Sistrunk procedure alone is recommended for papillary thyroid cancer in lowrisk patients who are female and younger than 40 years old, with no invasion of the capsule and a low-grade tumor of less than $1 \mathrm{~cm}$ in size.

In the case of large tumors $>1 \mathrm{~cm}$, invasion through the duct cyst wall, or suspect foci in the thyroid gland, a total thyroidectomy followed by I131 ablation and thyroidstimulating hormone suppression is the most frequently proposed treatment. ${ }^{14}$ In pure squamous cell carcinomas of TG cyst, the Sistrunk procedure is the only warranted procedure.

Regarding MEC, the low-grade tumors can be treated by Cistrunk's operation but aggressive treatment is warranted in high-grade tumors and the available literature supports the use of adjuvant radiotherapy in cases of high-grade tumors, which generally carry a poor prognosis. ${ }^{15}$ The use of radioiodine ablation due to the possible origins of these tumors having dedifferentiated from other thyroid neoplasms has been advocated by some authors. ${ }^{16}$

Regarding cervical lymph nodes, even if these are not palpable, clinically frozen sections are considered to be

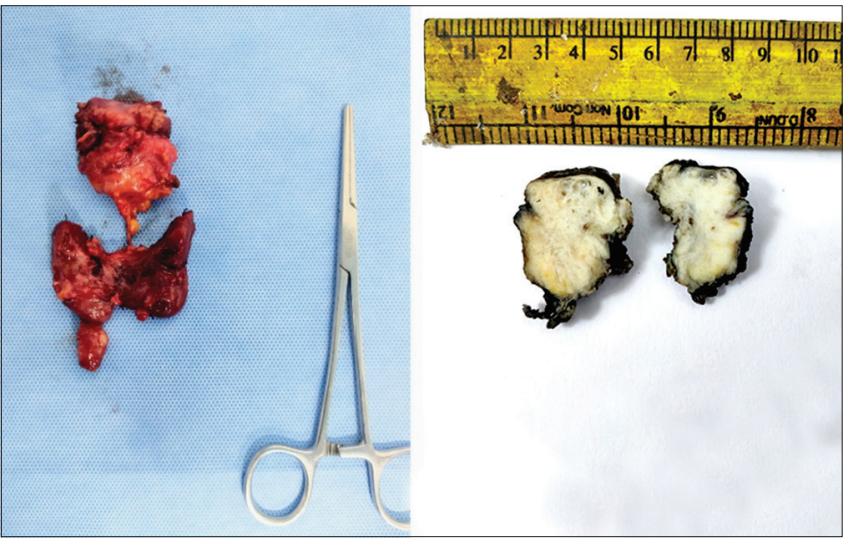

Figure 2: Macroscopic specimen from total thyroidectomy and Sistrunk operation: A single nodular mass measuring $4.5 \times 3.2 \times 3 \mathrm{~cm}$, with attached hyoid bone. Cut surface demonstrates ill-defined tumor mass with interspersed cysts

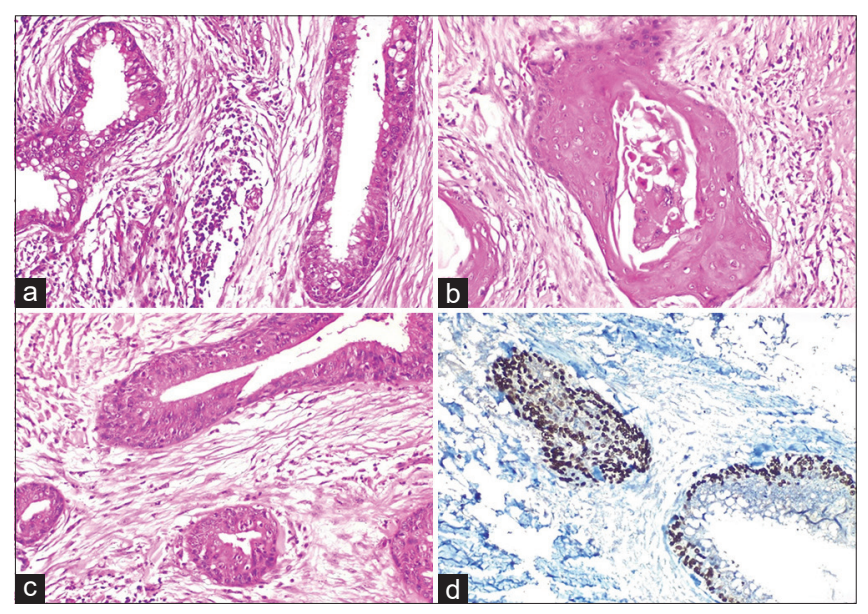

Figure 3: Microscopic histopathology demonstrating (a) mucus secreting cells, (b) intermediate cells, and (c) epidermoid cells in the high-power view. (d) p63 immunohistochemistry confirms epidermoid differentiation

mandatory. Radical or modified radical neck dissection is indicated only in the presence of positive lymph nodes. ${ }^{17}$ As the frequency of nodal metastasis is relatively small the survival is $95.5 \%$ at 10 years.

\section{CONCLUSION}

We are reporting an usual histological surprise in a thyroglossal cyst malignancy being the only second reported case of TG cyst mucoepidermoid. This case highlights the importance of removal of thyroglossal duct cysts at an early stage and aggressive surgical approach in high-grade tumors.

\section{REFERENCES}

1. Organ GM and Organ $\mathrm{CH}$ Jr. Thyroid gland and surgery of the thyroglossal duct: Exercise and applied embryology. World $\mathrm{J}$ 
Surg. 2000;24(8):886-890.

https://doi.org/10.1007/s002680010172

2. Allard RH. The thyroglossal cyst. Head Neck Surg. 1982;5(2):134-146.

3. Fumarola A, Trimboli P, Cavaliere R, Coletta I, Veltri A, Di Fiore A et al. Thyroid papillary carcinoma arising in ectopic thyroid tissue withina neck branchial cyst. World J Surg Oncol. 2006;4:24. https://doi.org/10.1186/1477-7819-4-24

4. El Bakkouri W, Racy E, Vereecke A, Gauthier A, Quillard J, Bobin S, et al. Squamous cell carcinoma in a thyroglossal duct cyst. Ann Otolaryngol Chir Cervicofac. 2004;121(5):303-305.

5. Carter $\mathrm{Y}$, Yeutter $\mathrm{N}$ and Mazeh $\mathrm{H}$. Thyroglossal duct remnant carcinoma: Beyond the Sistrunk procedure. Surg Oncol. 2014;23(3):161-166.

https://doi.org/10.1016/j.suronc.2014.07.002

6. Tew S, Reeve TS, Poole AG and Delbridge L. Papillary thyroid carcinoma arising in thyroglossal duct cysts: incidence and management. Aust N Z J Surg. 1995;65(10):717-718.

https://doi.org/10.1111/j.1445-2197.1995.tb00543.x

7. Behboudi A, Enlund F, Winnes M, Andrén Y, Nordkvist A, Leivo I, et al. Molecular classification of mucoepidermoid carcinomasprognostic significance of the MECT1-MAML2 fusion oncogene. Genes Chromosomes Cancer. 2006;45(5):470-481.

https://doi.org/10.1002/gcc.20306

8. Jee K, Persson M, Heikinheimo K, Passador-Santos F, Aro K, Knuutila S, et al. Genomic profiles and CRTC1-MAML2 fusion distinguish different subtypes of mucoepidermoid carcinoma. Mod Pathol. 2012;26(2):213-222.

https://doi.org/10.1038/modpathol.2012.154

9. Tirado Y, Williams MD, Hanna EY, Kaye FJ, Batsakis JG and El-Naggar AK. CRTC1/MAML2 fusion transcript in high grade mucoepidermoid carcinomas of salivary and thyroid glands and Warthin's tumors: Implications for histogenesis and biologic behaviour, Genes Chromosomes Cancer. 2007;46(7):708-715. https://doi.org/10.1002/gcc.20458

10. Minagawa M, litaka M, Suzuki, Yasuda S, Kameyama K, Shimada S, et al. A case of primary mucoepidermoid carcinoma of the thyroid: molecular evidence of its origin. Clin Endocrinol. 2002;57(4):551-556

https://doi.org/10.1046/j.1365-2265.2002.01599.x

11. Wenig B, Adair C and Heffess C. Primary mucoepidermoid carcinoma of the thyroid gland: A report of six cases and a review of the literature of a follicular epithelial-derived tumor. Hum Pathol. 1995;26(10):1099-1108.

https://doi.org/10.1016/0046-8177(95)90272-4

12. Friedmann, Histological typing of salivary gland tumours. In: Seifert G, editor. Collaboration of Pathologists from Six Countries. Berlin: Springer; 1991. https://doi.org/10.1017/s0022215100118717

13. Garden AS, El-Naggar AK, Morrison WH, Callender DL, Ang KK and Peters LJ. Postoperative radiotherapy for malignant tumors of the parotid gland. Int J Radiat Oncol Biol Phys. 1997;37(1):79-85. https://doi.org/10.1016/s0360-3016(96)00464-6

14. Wexler MJ. Surgical management of thyroglossal duct carcinoma: Is an aggressive approach justified? Can J Surg. 1996;39(4):263-264.

15. Shindo K, Aishima S, Okido M and Ohshima A. A poor prognostic case of mucoepidermoid carcinoma of the thyroid: A case report. Case Rep Endocrinol. 2012;2012:862545. https://doi.org/10.1155/2012/862545

16. Kristensen S, Juul A, Moesner J. Thyroglossal cyst carcinoma. J Laryngol Otol. 1984;98:1277-1280. https://doi.org/10.1017/s0022215100148406

17. Hartl DM, Al Ghuzlan A, Chami L, Leboulleux S, Schlumberger M, Travagli JP, et al. High rate of multifocality and occult lymph node metastases in papillary thyroid carcinoma arising in thyroglossal duct cysts. Ann Surg Oncol. 2009;16(9):2595-2601. https://doi.org/10.1245/s10434-009-0571-9

\section{Authors Contribution:}

RC- Treating consultant and manuscript concept design and preparation; NCR- Review of manuscript; BPJ- Consultant in charge; APM- Pathologist and manuscript contribution; STV- Surgical consultant and manuscript review.

\section{Work attributed to:}

Government Medical College, Thrissur, Kerala, India

\section{Orcid ID:}

Ravindran Chirukandath - (i) https://orcid.org/0000-0002-0562-1952

Nimisha CR - iD https://orcid.org/0000-0002-8530-4059

Babu PJ - (1) https://orcid.org/0000-0003-1650-3609

Arya Puthukatt Muraleedharan - (1) https://orcid.org/0000-0002-3431-0889

Lekshmi RS - io https://orcid.org/0000-0001-7430-8903

Santhosh TV- (1) https://orcid.org/0000-0001-7301-8269

Source of Funding: None, Conflicts of Interest: None. 